\title{
Melasma: an Up-to-Date Comprehensive Review
}

\author{
Oluwatobi A. Ogbechie-Godec · Nada Elbuluk
}

Received: April 24, 2017 / Published online: July 19, 2017

(C) The Author(s) 2017. This article is an open access publication

\begin{abstract}
Melasma is a common acquired condition of symmetric hyperpigmentation, typically occurring on the face, with higher prevalence in females and darker skin types. Multiple etiologies, including light exposure, hormonal influences, and family history, have been implicated in the pathogenesis of this disorder. Overall prevalence ranges widely at $1-50 \%$, since values are typically calculated within a specific ethnic population within a geographic region. Histologically, melasma can display increased epidermal and/or dermal pigmentation, enlarged melanocytes, increased melanosomes, solar elastosis, dermal blood vessels, and, occasionally, perivascular lymphohistiocytic infiltrates. Various topical, oral, and procedural therapies have been successfully used to treat melasma. Traditional topical therapies including hydroquinone, tretinoin, corticosteroids, and triple combination creams; however, other synthetic and natural topical compounds have also shown varying efficacies. Promising oral therapies for melasma include tranexamic acid,
\end{abstract}

Enhanced content To view enhanced content for this article go to http://www.medengine.com/Redeem/ C1E8F0602EB3D30A.

O. A. Ogbechie-Godec $\cdot$ N. Elbuluk $(\varangle)$

Ronald O. Perelman Department of Dermatology,

New York University, New York, NY, USA

e-mail: nada.elbuluk@nyumc.org
Polypodium leucotomos, and glutathione. Procedures, including chemical peels, microneedling, radiofrequency, and lasers, are also often used as primary or adjunctive treatments for melasma. Notably, combination therapies within or across treatment modalities generally result in better efficacies than monotherapies. This review serves as a comprehensive update on the current understanding of the epidemiology, pathogenesis, clinical and histologic features of melasma, as well as treatments for this common, yet therapeutically challenging, condition.

Keywords: Hyperpigmentation; Melasma; Pigmentary disorders; Skin of color

\section{INTRODUCTION}

Melasma, formerly known as chloasma, is an acquired pigmentary condition, occurring most commonly on the face. This disorder, which is more prevalent in females and darker skin types, is predominantly attributed to ultraviolet (UV) exposure and hormonal influences. Melasma is generally a clinical diagnosis consisting of symmetric reticulated hypermelanosis in three predominant facial patterns: centrofacial, malar, and mandibular [1]. The major clinical pattern in $50-80 \%$ of cases is the centrofacial pattern, which affects the forehead, nose, and 
upper lip, excluding the philtrum, cheeks, and chin $[2,3]$. The malar pattern is restricted to the malar cheeks on the face, while mandibular melasma is present on the jawline and chin. The latter is thought to occur in older individuals and may be more related to severe photodamage [4]. A newer pattern termed extra-facial melasma can occur on non-facial body parts, including the neck, sternum, forearms, and upper extremities [5]. Though common, the management of this disorder remains challenging given the incomplete understanding of the pathogenesis, its chronicity, and recurrence rates. In addition to traditional treatments for melasma, there are also promising new treatments, including topical, oral, and procedural therapies. This review will provide an up-to-date overview of the current literature on melasma, including clinical diagnosis, pathogenesis, and treatments including discussion of new topical, oral, and procedural therapies. This article is based on previously conducted studies and does not involve new studies of human or animal subjects performed by the authors.

\section{Diagnosis}

Morphologically, melasma presents as symmetric reticulated hyperpigmented patches with irregular borders on the centrofacial region, malar cheeks, mandible, and rarely upper chest and extremities. While melasma is known to more commonly affect darker skin types, it can occur in all skin types $[2,3,6]$. On dermoscopic examination, it is possible to see pronounced hyperpigmentation in the pseudo-rete ridges of the skin [7]. Using a Wood's lamp, the hyperpigmentation can be accentuated when the pigment is epidermal [8]. However, this accentuation may be seen with dermal or mixed melasma $[1,9]$. Reflectance confocal microscopy (RCM) has also been used to evaluate melasma on a cellular level. In the epidermis, it has shown an increase in hyperrefractile cobblestoning cells which corresponded to hyperpigmented basal keratinocytes on histology [10]. In some patients, epidermal dendritic cells can also be found corresponding to activated melanocytes. In the dermis, RCM may show plump bright cells corresponding to melanophages as well as solar elastosis and blood. RCM is a non-invasive technique that detects pigmentary changes in melasma at a cellular level resolution [10]. The differential diagnosis for melasma includes lichen planus pigmentosus, discoid lupus erythematosus, phototoxic dermatitis, erythema dyschromium perstans, phytophotodermatitis, pigmented contact dermatitis, drug-induced pigmentation, poikiloderma of Civatte, erythromelanosis follicularis faciei, ochronosis, hori's nevus, argyria, nevus of ota, lentigines, ephelides, macular amyloidoses, and post-inflammatory hyperpigmentation [11].

\section{Epidemiology}

Various epidemiologic studies have estimated the prevalence of melasma in the general population at $1 \%$ and in higher-risk populations at 9-50\% [12-15]. These wide ranges are secondary to variations in prevalence among darker skin types, different ethnic heritages, and different levels of UV exposure within various geographic locations. As such, the true prevalence across the entire population is unknown. The age of onset is also unknown, with average age ranging being between 20 and 30 years [3, 8]. One study argued that patients with mandibular melasma have an older age of onset in their 40s [4].

Many studies have attempted to calculate the prevalence and incidence of melasma from data available in dermatology clinics. However, this approach may underestimate the number of affected individuals given that some patients with milder disease may forgo clinical evaluation, as well as the potential for misdiagnoses. A prospective telephone-based study in a community of Latino women in the southwestern United States found a prevalence of $8.8 \%$ amongst 500 interviewed individuals [14]. Another prospective study on melasma prevalence in a New York City dermatology private practice found a prevalence of $8.2 \%$ amongst 1000 Latino patients [16]. Globally, the prevalence of melasma has also varied. A study of 3298 people in Saudi Arabia revealed a 2.9\% 
prevalence, compared to a prevalence of $13.4-15.5 \%$ seen in an Arab-American population in Michigan [17, 18]. Additionally, a retrospective study in a health center in Ethiopia demonstrated a $1.5 \%$ prevalence [19].

Studies have shown that melasma has a female predominance $[6,8,20]$. Although the general accepted female to male ratio is 9:1, a more recent large, multicenter study of 953 melasma patients in Brazil found a 39:1 ratio $[6,20]$. An Indian study of 312 patients with melasma found a 4:1 female to male ratio [8]. During pregnancy, the prevalence likely increases, which was seen in a cross-sectional study in Tehran with a $15.8 \%$ prevalence amongst pregnant women. Similarly, in a randomly selected sample of 2000 pregnant women in India, there was a $50.8 \%$ prevalence $[12,13]$. Fewer studies have been carried out on men with melasma, but they clinically tend to exhibit similar clinical features and exacerbating factors [21]. Two major risk factors found in Indian and Latino men include sun-exposure and outdoor work $[21,22]$.

\section{Pathogenesis}

The etiology of melasma is multifactorial. UV light has been shown in clinical and laboratory studies to trigger and exacerbate the condition [8]. UV light is thought to induce reactive oxygen species (ROS) by activating inducible nitric oxide and promoting melanogenesis [23]. Patients with melasma have also been found to have higher markers of oxidative stress when compared to healthy volunteers [24]. More recently, the role of visible light in inducing pigmentation has been appreciated. A seminal study showed sustained pigmentation from visible light in darker skin types over 2 weeks compared to pigmentation from UVA-1 light [25]. Another study showed that visible light at a wavelength of $415 \mathrm{~nm}$ can cause increased pigmentation that could last for 3 months [26].

The process of melanogenesis after UV and visible light exposure can be stimulated by keratinocytes and fibroblasts. One major pathway of both UV- and visible light-induced pigmentation is the secretion of stem cell factor (SCF), the ligand for the tyrosine kinase receptor, c-kit, which leads to downstream effects on the proliferation of melanocytes [27]. A recent study showed the increased expression of SCF in the dermis and c-kit in the epidermis in areas of melasma [27]. This is further supported by increased mRNA levels of melanogenesis-associated genes [28]. Other studies have found increased levels of Wnt signaling-related genes, which is notable since Wnt has been linked to the proliferation of melanocyte stem cells [28, 29]. Additionally, vascular endothelial growth factor (VEGF), a product of keratinocytes after UV damage, can sustain human melanocytes in tissue culture [30]. This is proposed as one of the mechanisms for the increased activity of melanocytes in melasma $[30,31]$. Recent gene and protein expression studies have also shown down-regulation of lipid metabolism-associated genes in lesional skin, which may suggest impaired barrier function as contributing to the pathogenesis of melasma [28].

Family history is also known to be an important risk factor for developing melasma, strengthening the hypothesis of a genetic predisposition to the condition. Some studies have reported that $55-64 \%$ of patients with this condition have a positive family history $[12,32,33]$. No genome-wide study has been performed to examine associated genes, but current findings would suggest that the genes responsible involve pigmentary, inflammatory, hormonal, and possibly vascular responses. Patients with Fitzpatrick skin type (FST) II and III are less likely to have a positive family history than patients with darker skin types (IV-VI) $[6,34]$.

Hormonal influences play a significant role in the pathogenesis of melasma as seen by the increased prevalence with pregnancy, oral contraceptive use and other hormonal therapies $[2,3,33,34]$. Extra-facial melasma has also been associated with a peri-menopausal state $[5,6]$. An immunohistochemical study of the epidermis and dermis of affected and unaffected neighboring skin found significantly increased expression of the progesterone receptor in the epidermis of affected skin [35]. There was also increased estrogen receptor protein expression 
in the dermis and around the blood vessels, which is currently of unknown significance [36].

Melasma has not been consistently associated with other clinical conditions. In a case-control study, melasma was shown to be associated with an increased number of lentigines and nevi [32]. Endocrinological conditions, such as thyroid disease, have also been investigated as having an association with melasma, but observed prevalence of thyroid diseases in these studies are not increased when compared to the general population $[8,37]$.

\section{Histology}

Historically, melasma has been classified as having three histologic variants: epidermal, dermal, and mixed [1]. In the epidermal type, there is increased pigment throughout the layers of the epidermis, particularly in the basal and suprabasilar layers. Melanocytes in the epidermis are generally enlarged, have prominent dendrites, and increased melanosomes $[9,38]$. Although one study suggested an increase in melanocyte number, most studies report no change in the number of epidermal melanocytes [38]. Epidermal pigmentation may be accentuated with a Wood's lamp which may help distinguish epidermal and dermal subtypes. The dermal subtype has melanophages in the superficial and deep dermis. Additionally, a lymphohistiocytic infiltrate may be seen in the dermis in areas with increased melanin deposition. Dermal findings can also include solar elastosis and an increase in blood vessels $[9,11]$. Mixed melasma often displays combined histologic features of the epidermal and dermal subtype.

\section{Clinical Assessment and Psychosocial Implications}

Given the variability of presentation, assessing melasma severity can be challenging. Several validated tools have been created to evaluate both the clinical appearance and the psychosocial impact of dyspigmentation from melasma. Moreover, these standardized tools have enhanced the ability to assess therapeutic efficacy of various melasma treatments in clinical trials. The Melasma Area and Severity Index (MASI) is a validated scale used to measure the extent of facial hyperpigmentation. This is a numeric score calculated as an area-weighted score of pigmentation and homogeneity located on the forehead, chin, right and left malar cheek [39]. After eliminating homogeneity from the calculation due to the decreased interrater reliability of that metric, the modified MASI (mMASI) was created [39]. It has now been correlated to the Melasma Severity Score, which is a global score that incorporates both objective data and patient's subjective assessment. It is now used in clinical trials [40]

For many dermatologic conditions, a health-related quality of life (HRQoL) tool has been used to measure the psychosocial aspects of skin diseases. Balkrishnan and colleagues created the Melasma Quality Of Life Scale (MELASQOL), a validated modified version of the HRQoL [41]. The scale consists of 10 questions pertaining to the quality of life and impact of the disease rated on a Likert scale. Other psychometric scales that can be used in those with melasma are the Dermatology Life Quality Index (DLQI) and the SKINDEX-16 [42-46].

\section{Treatment}

Treatments for melasma include topical, oral, procedural, and combination treatments. These are aimed at various aspects of the pathogenesis of melasma including photodamage, inflammation, vascularity, and pigmentation (Table 1).

\section{Topical}

Topical treatments, including photoprotection, are typically the first-line therapies for melasma. The most common therapeutic agents used are those that inhibit the production of melanin through melanogenesis and melanocyte proliferation. Concomitant use of various topical therapies with different mechanisms of action are preferred to monotherapy. 
Table 1 Melasma treatments, mechanisms of action, and adverse effects

\begin{tabular}{|c|c|c|c|}
\hline Modality & Treatment & Mechanism of action & Adverse effects (AE) \\
\hline \multirow[t]{9}{*}{ Topical } & Iron oxide & Block visible and ultraviolet light & Irritation \\
\hline & $\begin{array}{l}\text { Hydroquinone } \\
\text { (HQ), }\end{array}$ & Tyrosinase inhibitor & Irritation, exogenous ochronosis (with HQ) \\
\hline & Azelaic acid, & & \\
\hline & Ascorbic acid, & & \\
\hline & Kojic acid & & \\
\hline & Tretinoin & Increased keratinocyte turnover & Irritation, redness \\
\hline & Corticosteroids & $\begin{array}{l}\text { Anti-inflammatory with non-selective } \\
\text { inhibition of melanogenesis }\end{array}$ & $\begin{array}{l}\text { Telangiectasias, epidermal atrophy, } \\
\text { steroid-induced acne, striae, } \\
\text { hypopigmentation }\end{array}$ \\
\hline & Ascorbic acid & Inhibition of reactive oxygen species & No significant $\mathrm{AE}$ \\
\hline & Niacinamide & Inhibition of melanosome transfer & Irritation \\
\hline \multirow[t]{3}{*}{ Oral } & Tranexamic acid & $\begin{array}{l}\text { Inhibits plasminogen/plasmin pathway } \\
\rightarrow \text { inhibition of melanin synthesis }\end{array}$ & $\begin{array}{l}\text { Abdominal bloating, menstrual irregularities, } \\
\text { headache, deep venous thrombosis }\end{array}$ \\
\hline & & Decreases vascular proliferation & \\
\hline & $\begin{array}{l}\text { Polypodium } \\
\text { leucotomos, } \\
\text { Glutathione }\end{array}$ & Inhibition of reactive oxygen species & No significant $\mathrm{AE}$ \\
\hline \multirow[t]{7}{*}{ Procedural } & $\begin{array}{l}\text { Q-switch ruby laser, } \\
\text { Q-switch Nd:Yag } \\
\text { laser }\end{array}$ & Melanosome destruction & $\begin{array}{l}\text { Burn, post inflammatory pigment alteration } \\
\text { (PIPA) }\end{array}$ \\
\hline & $\begin{array}{l}\text { Non-ablative } \\
\text { fractional lasers }\end{array}$ & $\begin{array}{l}\text { Fractional photothermolysis leading to } \\
\text { melanin extrusion }\end{array}$ & Burn, PIPA \\
\hline & Chemical peels & Increased keratinocyte turnover & Burn, peeling, PIPA \\
\hline & Microneedling & Transdermal drug delivery & Erythema, edema, tram-track marks, PIPA \\
\hline & Intense pulsed light & Extrusion of melanosomes & Burn, PIPA \\
\hline & Radiofrequency & Cellular biostimulation & Burn \\
\hline & & Transdermal drug delivery & \\
\hline
\end{tabular}

$\overline{A E \text { adverse effects, } H Q \text { hydroquinone, } P I P A \text { post-inflammatory pigment alteration, } N d: Y A G \text { neodymium-doped yttrium }}$ aluminum garnet

\section{Photoprotection}

UV and visible light avoidance are critical to prevent flares and exacerbation of melasma. In repeated randomized-controlled studies with 40-60 subjects, a comparison of broad-spectrum
UVA and UVB filters combined with visible light blockers, such as iron oxide, versus broad-spectrum UV filters alone showed reduced melasma relapses in the former group [47-49]. 


\section{Hydroquinone}

Hydroquinone (HQ) has historically been the most studied topical agent in the treatment of melasma. This compound works by inhibiting tyrosinase, which prevents the conversion of DOPA to melanin [50]. Others have postulated that it can also directly lead to melanocyte destruction and melanosome degradation. In several studies, the use of HQ $4 \%$ has led to a statistically significant improvement of melasma dyspigmentation [46, 51]. Although very effective and dosed at different strengths, it can cause an irritant dermatitis in some individuals and chronic use can lead to exogenous ochronosis [7].

\section{Corticosteroids}

Corticosteroids can prevent pigmentation by non-selective suppression of melanogenesis while also serving as an anti-inflammatory agent [52]. Corticosteroids alone are unlikely to be superior to depigmenting agents when used as monotherapy [52]. Although they have an independent ability to suppress melanogenesis, the current literature shows that corticosteroids have not been demonstrated to have long-term benefits in treating melasma [50]. Moreover, long-term steroid use may lead to telangiectasias, acne, epidermal atrophy, striae, and hypopigmentation.

\section{Retinoids}

Topical retinoids have also been effective in treating melasma, with a postulated mechanism of promoting keratinocyte turnover [53]. A small but sentinel study in 1993 showed that tretinoin $0.1 \%$ cream could significantly decrease objective colorimetry measurements of melasma pigmentation [53]. Another study has confirmed the beneficial use of tretinoin $0.1 \%$ cream for the treatment of melasma in Black patients [54].

\section{Other Synthetic Topical Compounds}

Another tyrosinase inhibitor, 4-n-butylresorcinol, has been increasingly used in trials and has shown significant improvement in pigmentation in melasma $[55,56]$. Noted adverse effects, including erythema and pruritus, were self-limited and minimal; however, long-term data on this product is lacking. Tranexamic acid, a synthetic version of lysine and a hemostatic agent, has been increasingly used in the topical, oral, and injectable forms to treat melasma. Studies have demonstrated occasional negative findings when used as a monotherapy, but increased efficacy when used in combination with other pigmentation-based therapies [57-61]. The topical formulation of tranexamic acid, however, has had limited success and less efficacy than when used in oral form. Topical flutamide, an antiandrogenic agent, has also been studied in comparison to HQ 4\%, and was found to have statistically significant MASI scores and patient satisfaction; however, no difference in the mexameter melanin assay was observed between the two groups [62].

\section{Natural Topical Compounds}

In recent years, naturally occurring compounds have been investigated for their therapeutic activity against pigmentation. Niacinamide, which inhibits melanosome transfer to keratinocytes, has been shown to decrease pigmentation in a small study with 27 subjects [63]. Both ascorbic acid and kojic acid can inhibit tyrosinase activity and have been shown in small studies to lead to decreased pigmentation [46, 63-65]. Ascorbic acid has a theorized benefit of decreasing reactive oxygen species, which decreases inflammation in melasma lesions [23, 65]. However, both were shown to be inferior to HQ in improving MASI scores when used as monotherapies [51, 52, 66]. Another natural compound, azelaic acid (AA), was noted in an open-label study to be effective in improving pigmentation by inhibiting tyrosinase activity [43]. This compound, which is derived from the yeast, Pityrosporum ovale, also has anti-inflammatory effects. Adverse effects are not common, but can include burning and erythema. Bellis perennis, a flower extract that inhibits melanin synthesis, was demonstrated, in combination with topical licorice and emblica, another natural antioxidant, to be similar in efficacy to HQ $2 \%$ in decreasing pigmentation and inhibiting inflammation through the arachidonic acid 
cascade [67]. Other topical natural compounds used, such as lignin peroxidase, arbutin, and soy, have also been used to treat melasma in small studies with favorable results [63, 68-70].

\section{Combination Topical Compounds}

Recent studies have shown that combination topical therapies are superior to monotherapies in efficacy [71]. Triple combination therapy (TCT) with HQ, a retinoid, and a topical steroid was the first combination topical therapy to gain United States Food and Drug Administration approval. In an investigator-blinded randomized study with 260 Asian patients, TCT with HQ $4 \%$, tretinoin $0.05 \%$, and fluocinolone acetonide $0.01 \%$ was superior to HQ $4 \%$ monotherapy in improving melasma [72]. Of note, about $50 \%$ of patients on TCT reported increased erythema, skin irritation, and discomfort when compared to $14 \%$ of controls. Dual therapy with tretinoin $0.1 \%$ and HQ 3\% was also demonstrated to improve melasma among female Korean patients [73].

\section{Camouflage}

With the recurring nature of melasma and the long, challenging treatment duration, cosmetic camouflage can provide patients with another option to improve the psychosocial effects of the condition and quality of life. Cosmetic camouflage, including concealers and other pigmented cover-ups, has been shown to significantly improve the DLQI in a study of 24 patients with pigmentary disorders [74]. Several cosmetics brands offer pigmented foundations and concealers that may even skin complexion and may also include broad-spectrum UV blockers.

\section{Oral}

In addition to topical therapies, oral therapies are emerging as additional treatment options for this disorder. Tranexamic acid (TA), an anti-plasmin agent, decreases the generation of arachidonic acid, which leads to a reduction in melanocyte-stimulating hormone (MSH) and a decrease in pigmentary production [60]. One study showed that TA may also decrease VEGF and entothelin-1, both of which may be responsible for increasing vascularity in affected lesions [44]. While formulations of tranexamic acid have not been directly compared, recent studies generally suggest that about $90 \%$ of patients treated orally improved after 2-6 months compared to about $95 \%$ of patients treated with topical $2 \%$ preparations and who improved after 3 months $[44,60,61]$. Notable adverse effects of oral TA include abdominal bloating, headache, tinnitus, menstrual irregularities, and, rarely, deep venous thrombosis (DVT) [60]. Due to the serious risk of a DVT, screening for risk factors of thrombosis is necessary before initiating treatment.

Alternative medications, such as Polypodium leucotomos (PL) and glutathione, have also been studied as adjunctive treatments with positive results [75-77]. PL has been shown to decrease UV-induced photodamage and inhibit ROS, which in turn decreases the $\mathrm{T}$ cell-mediated response that leads to increased inflammation and pigmentation in the skin [76]. In a randomized controlled trial in the Philippines, oral glutathione, a naturally occurring compound, resulted in decreased melanin when compared to those taking placebo over a 4 -week period [77]. Glutathione is thought to act as an anti-oxidant that decreases inflammation [63].

\section{Procedural}

The recent literature on procedural melasma therapies has predominantly included case reports and case series that evaluate the use of chemical peels, microneedling, microdermabrasion, and lasers, typically in conjunction with other treatment modalities. It is important to note that many procedural studies include concomitant use of topical therapies and photoprotection [31, 78-82].

\section{Chemical Peels}

Chemical peels have been studied as an adjunctive treatment modality for melasma due to their ability to increase epidermal remodeling and to increase keratinocyte turnover. Chemical peels are frequently used in combination with other topical products [83]. Several studies have suggested that superficial peels may be beneficial for the epidermal-subtype of 
melasma [83, 84]. Amongst the various peels, glycolic acid (GA) has been most extensively studied in the treatment of melasma. A small open-label study found that $30-50 \%$ GA peels at 3 -week intervals for 6 months in addition to AA $20 \%$ twice-daily regimen resulted in superior MASI scores when compared to AA 20\% alone [45]. However, a small split-face study found no difference in decreased pigmentation when using HQ 4\% with GA 20-30\% compared to HQ alone [85]. Another split-face study showed no difference in a regimen with salicylic acid (SA) $20-30 \%$ peel and HQ 4\% compared to HQ monotherapy [86].

Combination peels have also been explored in recent studies. A study in India found that a combination of $20 \%$ SA and $10 \%$ mandelic acid was equally as efficacious as $35 \%$ GA over 12 weeks in significantly improving MASI scores for FST IV and V patients [42]. Trichloroacetic acid (TCA) $10-20 \%$ peels were shown to have similar efficacy to GA peels but with more adverse effects, such as burning and peeling [87].

\section{Microneedling}

Another adjunctive treatment is microneedling or mesotherapy, which creates small channels in the skin to deliver small amounts of topical drugs intradermally $[56,58,88]$. The skin punctures induced by microneedling can also stimulate a beneficial wound-healing response with fewer side effects compared to conventional resurfacing procedures [89]. This technique may result in a deeper and more even placement of the medication to the epidermis and dermis [58, 88]. In a randomized study using multiple microinjections of TA intradermally compared to cycles of microneedling alone followed by the application of topical TA, the data showed possible clinical benefit with use of microneedling but no statistically significant benefit [58]. A prospective study of patients treated with topical lightening agents, rucinol and sophora-alpha, alone compared to use of those topicals with microneedling demonstrated a significant improvement in MASI scores when administered with microneedling [56]. A limitation, however, is that the study was not blinded to either the patient or the investigator.

\section{Laser and Light Treatments}

In more recent years, laser therapy has been investigated to treat melasma with varying success. Lasers can utilize thermal energy to selectively target various chromophores in the skin. Non-ablative lasers are preferred for the treatment of melasma over ablative lasers given the tendency to cause less inflammation and subsequently less post-inflammatory pigment alteration (PIPA). Non-ablative Q-switched lasers, including the Q-switched ruby laser (QSRL) and Q-switched neodymium:yttrium-aluminium-garnet (QNd:YAG) lasers, selectively target the chromophore melanin [50]. When used as monotherapy, neither QSRL nor QNd:YAG have been found to have long-term benefits in treating melasma [80, 90-92]. However, one small study found that using low-dose fractional QSRL significantly decreased MASI scores [78]. More recent studies have found improvement in pigmentation with low fluence QNd:YAG, although the patients also applied sunscreen, HQ, tretinoin, or ascorbic acid after laser treatment [93, 94].

Intense pulsed light (IPL), has also been used successfully in several smaller studies for the treatment of melasma as a monotherapy and in combination with QSRL [95]. Fractionated IPL monotherapy used for melasma maintenance treatment resulted in improvement in mMASI scores over 14 weeks [95]. Some authors postulate that repeated IPL treatments may promote the upward shedding of the melanosomes destroyed by QSRL [80, 96]. Therefore, they suggest that combined IPL and QSRL therapy may decrease the risk of post-inflammatory hyperpigmentation (PIH) and therefore may also require more treatment sessions.

Other ablative lasers, such as carbon dioxide $\left(\mathrm{CO}_{2}\right)$, erbium:YAG (Er:YAG), and non-ablative fractional lasers, have also been used with varying success to treat melasma $[50,79,81]$. $\mathrm{CO}_{2}$ lasers have been used in clinical trials with Q-switched alexandrite lasers, but have been repeatedly found to be associated with PIH, especially at the periphery of lesions $[97,98]$. A 
recent split-face study using low-power $\mathrm{CO}_{2}$ laser versus QNd:YAG showed improved mMASI scores on the $\mathrm{CO}_{2}$ arm without a significant difference in adverse effects [99]. Er:YAG laser has also been shown in a small study with 20 patients to improve pigmentation using MASI scores, but recurrence was observed at 3-4 months [82]. Two studies that utilized a fractional nonablative 1550-nm erbium-doped fiber laser demonstrated improved pigmentation in about $60 \%$ of patients using investigator-created metrics [79, 81]. Neither study demonstrated long-term complications.

Other energy sources, such as monopolar radiofrequency (RF), have been used to treat melasma. RF causes cellular biostimulation, intracellular oxygenation, and vasodilatation [100]. In a prospective study of 50 patients, monopolar RF was used to deliver kojic acid with improved MASI scores and decreased inflammation, but there were no controls using only topical therapy, thus limiting data interpretation [100].

With increased recognition that inflammation and angiogenesis may play a role in the pathogenesis of melasma, a copper bromide anti-angiogenesis laser was evaluated in four Korean women who received 4 treatments over 8 weeks. Treatment was found to significantly decrease the MASI score and decrease endothelin-1 and VEGF on immunohistochemistry [31].

\section{CONCLUSIONS}

Melasma continues to be a frustrating condition to treat and one with significant psychosocial implications. Treatment efficacy can vary due to several factors including variability in clinical presentation and response to treatment amongst different genders, skin phototypes, and ethnicities. Given the multifactorial etiology of melasma, it is important to have a multimodal therapeutic approach that addresses factors such as photoprotection, inflammation, vascularity, pigmentation, and hormonal influences. New research continues to increase our understanding of melasma and how it can be best treated. The past decade has seen the emergence of new topical, oral, procedural, and combination therapies. Greater understanding of the pathogenesis of melasma will help in the development of future treatments for this common, yet challenging, condition.

\section{ACKNOWLEDGEMENTS}

No funding or sponsorship was received for this study or publication of this article. All named authors meet the International Committee of Medical Journal Editors (ICMJE) criteria for authorship for this manuscript, take responsibility of the integrity of the work as a whole, and have given final approval for the version to be published.

Disclosures. Oluwatobi A. Ogbechie-Godec and Nada Elbuluk have nothing to disclose.

Compliance with Ethics Guidelines. This article is based on previously conducted studies and does not involve any new studies of human or animal subjects performed by any of the authors.

Open Access. This article is distributed under the terms of the Creative Commons Attribution-NonCommercial 4.0 International License (http://creativecommons.org/licenses/ by-nc/4.0/), which permits any noncommercial use, distribution, and reproduction in any medium, provided you give appropriate credit to the original author(s) and the source, provide a link to the Creative Commons license, and indicate if changes were made.

\section{REFERENCES}

1. Sanchez NP, Pathak MA, Sato S, Fitzpatrick TB, Sanchez JL, Mihm MC Jr. Melasma: a clinical, light microscopic, ultrastructural, and immunofluorescence study. J Am Acad Dermatol. 1981;4(6):698-710 (PubMed PMID: 6787100).

2. Guinot C, Cheffai S, Latreille J, Dhaoui MA, Youssef $\mathrm{S}$, Jaber K, et al. Aggravating factors for melasma: a prospective study in 197 Tunisian patients. J Eur Acad Dermatol Venereol. 2010;24(9):1060-9 (PubMed PMID: 20202051). 
3. Tamega Ade A, Miot LD, Bonfietti C, Gige TC, Marques ME, Miot HA. Clinical patterns and epidemiological characteristics of facial melasma in Brazilian women. J Eur Acad Dermatol Venereol. 2013;27(2):151-6 (PubMed PMID: 22212073).

4. Mandry Pagan R, Sanchez JL. Mandibular melasma. P R Health Sci J. 2000;19(3):231-4 (PubMed PMID: 11076368).

5. Ritter CG, Fiss DV, Borges da Costa JA, de Carvalho RR, Bauermann G, Cestari TF. Extra-facial melasma: clinical, histopathological, and immunohistochemical case-control study. J Eur Acad Dermatol Venereol. 2013;27(9):1088-94 (PubMed PMID: 22827850).

6. Hexsel D, Lacerda DA, Cavalcante AS, Machado Filho CA, Kalil CL, Ayres EL, et al. Epidemiology of melasma in Brazilian patients: a multicenter study. Int J Dermatol. 2014;53(4):440-4 (PubMed PMID: 23967822).

7. Mishra SN, Dhurat RS, Deshpande DJ, Nayak CS. Diagnostic utility of dermatoscopy in hydroquinone-induced exogenous ochronosis. Int J Dermatol. 2013;52(4):413-7 (PubMed PMID: 22348652).

8. Achar A, Rathi SK. Melasma: a clinico-epidemiological study of 312 cases. Indian J Dermatol. 2011;56(4):380-2 (PubMed PMID: 21965843. Pubmed Central PMCID: 3178998).

9. Grimes PE, Yamada N, Bhawan J. Light microscopic, immunohistochemical, and ultrastructural alterations in patients with melasma. Am J Dermatopathol. 2005;27(2):96-101 (PubMed PMID: 15798432).

10. Kang HY, Bahadoran P, Suzuki I, Zugaj D, Khemis A, Passeron $\mathrm{T}$, et al. In vivo reflectance confocal microscopy detects pigmentary changes in melasma at a cellular level resolution. Exp Dermatol. 2010;19(8):e228-33 (PubMed PMID: 20497220).

11. Bagherani N, Gianfaldoni S, Smoller BR. An overview on melasma. J Pigment Disord. 2015;2(10):218.

12. Moin A, Jabery Z, Fallah N. Prevalence and awareness of melasma during pregnancy. Int J Dermatol. 2006;45(3):285-8 (PubMed PMID: 16533230).

13. Rathore SP, Gupta S, Gupta V. Pattern and prevalence of physiological cutaneous changes in pregnancy: a study of 2000 antenatal women. Indian J Dermatol Venereol Leprol. 2011;77(3):402 (PubMed PMID: 21508591).

14. Werlinger KD, Guevara IL, Gonzalez CM, Rincon ET, Caetano R, Haley RW, et al. Prevalence of self-diagnosed melasma among premenopausal
Latino women in Dallas and Fort Worth, Tex. Arch Dermatol. 2007;143(3):424-5 (PubMed PMID: 17372115).

15. Taylor SC. Epidemiology of skin diseases in ethnic populations. Dermatol Clin. 2003;21(4):601-7 (PubMed PMID: 14717401).

16. Sanchez MR. Cutaneous diseases in Latinos. Dermatol Clin. 2003;21(4):689-97 (PubMed PMID: 14717409).

17. Parthasaradhi A, Al Gufai AF. The pattern of skin diseases in Hail Region, Saudi Arabia. Ann Saudi Med. 1998;18(6):558-61 (PubMed PMID: 17344753).

18. El-Essawi D, Musial JL, Hammad A, Lim HW. A survey of skin disease and skin-related issues in Arab Americans. J Am Acad Dermatol. 2007;56(6):933-8 (PubMed PMID: 17321004).

19. Hiletework M. Skin diseases seen in Kazanchis health center. Ethiop Med J. 1998;36(4):245-54 (PubMed PMID: 11957300).

20. Vazquez M, Maldonado H, Benmaman C, Sanchez JL. Melasma in men. A clinical and histologic study. Int J Dermatol. 1988;27(1):25-7 (PubMed PMID: 3346120).

21. Sarkar R, Puri P, Jain RK, Singh A, Desai A. Melasma in men: a clinical, aetiological and histological study. J Eur Acad Dermatol Venereol. 2010;24(7):768-72 (PubMed PMID: 20015053).

22. Pichardo R, Vallejos Q, Feldman SR, Schulz MR, Verma A, Quandt SA, et al. The prevalence of melasma and its association with quality of life in adult male Latino migrant workers. Int J Dermatol. 2009;48(1):22-6 (PubMed PMID: 19126046. Pubmed Central PMCID: 2621062).

23. Jo HY, Kim CK, Suh IB, Ryu SW, Ha KS, Kwon YG, et al. Co-localization of inducible nitric oxide synthase and phosphorylated Akt in the lesional skins of patients with melasma. J Dermatol. 2009;36(1):10-6 (PubMed PMID: 19207431).

24. Seckin HY, Kalkan G, Bas Y, Akbas A, Onder Y, Ozyurt $\mathrm{H}$, et al. Oxidative stress status in patients with melasma. Cutan Ocular Toxicol. 2014;33(3):212-7 (PubMed PMID: 24147944).

25. Mahmoud BH, Ruvolo E, Hexsel CL, Liu Y, Owen $\mathrm{MR}$, Kollias $\mathrm{N}$, et al. Impact of long-wavelength UVA and visible light on melanocompetent skin. J Invest Dermatol. 2010;130(8):2092-7 (PubMed PMID: 20410914).

26. Duteil L, Cardot-Leccia N, Queille-Roussel C, Maubert Y, Harmelin Y, Boukari F, et al. Differences in 
visible light-induced pigmentation according to wavelengths: a clinical and histological study in comparison with UVB exposure. Pigment Cell Melanoma Res. 2014;27(5):822-6 (PubMed PMID: 24888214).

27. Kang HY, Hwang JS, Lee JY, Ahn JH, Kim JY, Lee ES, et al. The dermal stem cell factor and c-kit are overexpressed in melasma. $\mathrm{Br} \mathrm{J}$ Dermatol. 2006;154(6):1094-9 (PubMed PMID: 16704639).

28. Kang HY, Suzuki I, Lee DJ, Ha J, Reiniche P, Aubert J, et al. Transcriptional profiling shows altered expression of wnt pathway- and lipid metabolism-related genes as well as melanogenesis-related genes in melasma. J Invest Dermatol. 2011;131(8):1692-700 (PubMed PMID: 21562572).

29. Kim JY, Lee TR, Lee AY. Reduced WIF-1 expression stimulates skin hyperpigmentation in patients with melasma. J Invest Dermatol. 2013;133(1):191-200 (PubMed PMID: 22951732).

30. Kim EJ, Park HY, Yaar M, Gilchrest BA. Modulation of vascular endothelial growth factor receptors in melanocytes. Exp Dermatol. 2005;14(8):625-33 (PubMed PMID: 16026585).

31. Lee HI, Lim YY, Kim BJ, Kim MN, Min HJ, Hwang $\mathrm{JH}$, et al. Clinicopathologic efficacy of copper bromide plus/yellow laser $(578 \mathrm{~nm}$ with $511 \mathrm{~nm})$ for treatment of melasma in Asian patients. Dermatol Surg. 2010;36(6):885-93 (PubMed PMID: 20482724).

32. Adalatkhah H, Sadeghi-bazargani H, Amini-sani N, Zeynizadeh S. Melasma and its association with different types of nevi in women: a case-control study. BMC Dermatol. 2008;8:3 (Pubmed Central PMCID: 2525625).

33. Handel AC, Lima PB, Tonolli VM, Miot LD, Miot HA. Risk factors for facial melasma in women: a case-control study. $\mathrm{Br} \mathrm{J}$ Dermatol. 2014;171(3):588-94 (PubMed PMID: 24749693).

34. Ortonne JP, Arellano I, Berneburg M, Cestari T, Chan H, Grimes P, et al. A global survey of the role of ultraviolet radiation and hormonal influences in the development of melasma. J Eur Acad Dermatol Venereol. 2009;23(11):1254-62 (PubMed PMID: 19486232).

35. Jang YH, Lee JY, Kang HY, Lee ES, Kim YC. Oestrogen and progesterone receptor expression in melasma: an immunohistochemical analysis. J Eur Acad Dermatol Venereol. 2010;24(11):1312-6 (PubMed PMID: 20337826).

36. Tamega Ade A, Miot HA, Moco NP, Silva MG, Marques ME, Miot LD. Gene and protein expression of oestrogen-beta and progesterone receptors in facial melasma and adjacent healthy skin in women. Int J Cosmet Sci. 2015;37(2):222-8 (PubMed PMID: 25439299).

37. Lutfi RJ, Fridmanis M, Misiunas AL, Pafume O, Gonzalez EA, Villemur JA, et al. Association of melasma with thyroid autoimmunity and other thyroidal abnormalities and their relationship to the origin of the melasma. J Clin Endocrinol Metab. 1985;61(1):28-31 (PubMed PMID: 3923030).

38. Kang WH, Yoon KH, Lee ES, Kim J, Lee KB, Yim H, et al. Melasma: histopathological characteristics in 56 Korean patients. Br J Dermatol. 2002;146(2):228-37 (PubMed PMID: 11903232).

39. Pandya AG, Hynan LS, Bhore R, Riley FC, Guevara IL, Grimes P, et al. Reliability assessment and validation of the Melasma Area and Severity Index (MASI) and a new modified MASI scoring method. J Am Acad Dermatol. 2011;64(1):78-83, e1-2 (PubMed PMID: 20398960).

40. Rodrigues M, Ayala-Cortes AS, Rodriguez-Arambula A, Hynan LS, Pandya AG. Interpretability of the modified melasma area and severity index (mMASI). JAMA Dermatol. 2016;152(9):1051-2 (PubMed PMID: 27144383).

41. Balkrishnan R, McMichael AJ, Camacho FT, Saltzberg F, Housman TS, Grummer S, et al. Development and validation of a health-related quality of life instrument for women with melasma. Br J Dermatol. 2003;149(3):572-7 (PubMed PMID: 14510991).

42. Sarkar R, Garg V, Bansal S, Sethi S, Gupta C. Comparative evaluation of efficacy and tolerability of glycolic acid, salicylic mandelic acid, and phytic acid combination peels in melasma. Dermatol Surg. 2016;42(3):384-91 (PubMed PMID: 26859648).

43. Mazurek K, Pierzchala E. Comparison of efficacy of products containing azelaic acid in melasma treatment. J Cosmet Dermatol. 2016;15(3):269-82 (PubMed PMID: 27028014).

44. Kim SJ, Park JY, Shibata T, Fujiwara R, Kang HY. Efficacy and possible mechanisms of topical tranexamic acid in melasma. Clin Exp Dermatol. 2016;41(5):480-5 (PubMed PMID: 27135282).

45. Dayal S, Sahu P, Dua R. Combination of glycolic acid peel and topical $20 \%$ azelaic acid cream in melasma patients: efficacy and improvement in quality of life. J Cosmet Dermatol. 2016;16(1):35-42 (PubMed PMID: 27500896).

46. Shankar K, Godse K, Aurangabadkar S, Lahiri K, Mysore V, Ganjoo A, et al. Evidence-based treatment for melasma: expert opinion and a review. Dermatol Ther. 2014;4(2):165-86 (Pubmed Central PMCID: 4257945). 
47. Boukari F, Jourdan E, Fontas E, Montaudie H, Castela E, Lacour JP, et al. Prevention of melasma relapses with sunscreen combining protection against UV and short wavelengths of visible light: a prospective randomized comparative trial. J Am Acad Dermatol. 2015;72(1):189-90 e1 (PubMed PMID: 25443629).

48. Castanedo-Cazares JP, Hernandez-Blanco D, Carlos-Ortega B, Fuentes-Ahumada C, Torres-Alvarez B. Near-visible light and UV photoprotection in the treatment of melasma: a double-blind randomized trial. Photodermatol Photoimmunol Photomed. 2014;30(1):35-42 (PubMed PMID: 24313385).

49. Vazquez M, Sanchez JL. The efficacy of a broad-spectrum sunscreen in the treatment of melasma. Cutis. 1983;32(1):92, 5-6 (PubMed PMID: 6349944).

50. Gupta AK, Gover MD, Nouri K, Taylor S. The treatment of melasma: a review of clinical trials. J Am Acad Dermatol. 2006;55(6):1048-65 (PubMed PMID: 17097400).

51. Monteiro RC, Kishore BN, Bhat RM, Sukumar D, Martis J, Ganesh HK. A comparative study of the efficacy of $4 \%$ hydroquinone vs $0.75 \%$ kojic acid cream in the treatment of facial melasma. Indian J Dermatol. 2013;58(2):157 (PubMed PMID: 23716817. Pubmed Central PMCID: 3657227).

52. Deo KS, Dash KN, Sharma YK, Virmani NC, Oberai C. Kojic acid vis-a-vis its combinations with hydroquinone and betamethasone valerate in melasma: a randomized, single blind, comparative study of efficacy and safety. Indian J Dermatol. 2013;58(4):281-5 (PubMed PMID: 23918998. Pubmed Central PMCID: 3726874).

53. Griffiths CE, Finkel LJ, Ditre CM, Hamilton TA, Ellis $\mathrm{CN}$, Voorhees JJ. Topical tretinoin (retinoic acid) improves melasma. A vehicle-controlled, clinical trial. Br J Dermatol. 1993;129(4):415-21 (PubMed PMID: 8217756).

54. Kimbrough-Green CK, Griffiths CE, Finkel LJ, Hamilton TA, Bulengo-Ransby SM, Ellis CN, et al. Topical retinoic acid (tretinoin) for melasma in black patients. A vehicle-controlled clinical trial. Arch Dermatol. 1994;130(6):727-33 (PubMed PMID: 8002642).

55. Huh SY, Shin JW, Na JI, Huh CH, Youn SW, Park KC. The efficacy and safety of 4-n-butylresorcinol $0.1 \%$ cream for the treatment of melasma: a randomized controlled split-face trial. Ann Dermatol. 2010;22(1):21-5 (PubMed PMID: 20548876. Pubmed Central PMCID: 2883392).

56. Fabbrocini G, De Vita V, Fardella N, Pastore F, Annunziata MC, Mauriello MC, et al. Skin needling to enhance depigmenting serum penetration in the treatment of melasma. Plastic Surg Int. 2011;158241 (PubMed PMID: 22567235. Pubmed Central PMCID: 3335478).

57. Bagherani N, Smoller BR. Efficacy of topical tranexmic acid in the treatment of melasma. Dermatol Ther. 2016;29(6):389-90 (PubMed PMID: 26799239).

58. Budamakuntla L, Loganathan E, Suresh DH, Shanmugam S, Suryanarayan S, Dongare A, et al. A randomised, open-label, comparative study of tranexamic acid microinjections and tranexamic acid with microneedling in patients with melasma. J Cutan Aesthet Surg. 2013;6(3):139-43 (PubMed PMID: 24163529. Pubmed Central PMCID: 3800287).

59. Kanechorn $\mathrm{Na}$ Ayuthaya $\mathrm{P}$, Niumphradit $\mathrm{N}$, Manosroi A, Nakakes A. Topical 5\% tranexamic acid for the treatment of melasma in Asians: a double-blind randomized controlled clinical trial. J Cosmet Laser Ther. 2012;14(3):150-4 (PubMed PMID: 22506692).

60. Lee HC, Thng TG, Goh CL. Oral tranexamic acid (TA) in the treatment of melasma: a retrospective analysis. J Am Acad Dermatol. 2016;75(2):385-92 (PubMed PMID: 27206758).

61. Wu S, Shi H, Wu H, Yan S, Guo J, Sun Y, et al. Treatment of melasma with oral administration of tranexamic acid. Aesthetic Plast Surg. 2012;36(4):964-70 (PubMed PMID: 22552446).

62. Bagherani N. Efficacy of topical flutamide in the treatment of melasma. Dermatol Ther. 2016;29(5):297 (PubMed PMID: 27712039).

63. Alexis AF, Blackcloud P. Natural ingredients for darker skin types: growing options for hyperpigmentation. J Drugs Dermatol JDD. 2013;12(9 Suppl):s123-7 (PubMed PMID: 24002160).

64. Lim JT. Treatment of melasma using kojic acid in a gel containing hydroquinone and glycolic acid. Dermat Surg. 1999;25(4):282-4 (PubMed PMID: 10417583).

65. Kameyama K, Sakai C, Kondoh S, Yonemoto K, Nishiyama S, Tagawa $M$, et al. Inhibitory effect of magnesium L-ascorbyl-2-phosphate (VC-PMG) on melanogenesis in vitro and in vivo. J Am Acad Dermatol. 1996;34(1):29-33 (PubMed PMID: 8543691).

66. Espinal-Perez LE, Moncada B, Castanedo-Cazares JP. A double-blind randomized trial of 5\% ascorbic acid vs. $4 \%$ hydroquinone in melasma. Int J Dermatol. 2004;43(8):604-7 (PubMed PMID: 15304189).

67. Costa A, Moises TA, Cordero T, Alves CR, Marmirori $\mathrm{J}$. Association of emblica, licorice and belides as an 
alternative to hydroquinone in the clinical treatment of melasma. An Bras Dermatol. 2010;85(5):613-20 (PubMed PMID: 21152784).

68. Kimball AB, Kaczvinsky JR, Li J, Robinson LR, Matts PJ, Berge CA, et al. Reduction in the appearance of facial hyperpigmentation after use of moisturizers with a combination of topical niacinamide and $\mathrm{N}$-acetyl glucosamine: results of a randomized, double-blind, vehicle-controlled trial. Br J Dermatol. 2010;162(2):435-41 (PubMed PMID: 19845667).

69. Zhong SM, Sun N, Liu HX, Niu YQ, Wu Y. Reduction of facial pigmentation of melasma by topical lignin peroxidase: a novel fast-acting skin-lightening agent. Exp Ther Med. 2015;9(2):341-4 (PubMed PMID: 25574195. Pubmed Central PMCID: 4280934).

70. Morag M, Nawrot J, Siatkowski I, Adamski Z, Fedorowicz T, Dawid-Pac R, et al. A double-blind, placebo-controlled randomized trial of Serratula quinquefolia folium, a new source of beta-arbutin, in selected skin hyperpigmentations. J Cosmet Dermatol. 2015;14(3):185-90 (PubMed PMID: 26119285).

71. Kang WH, Chun SC, Lee S. Intermittent therapy for melasma in Asian patients with combined topical agents (retinoic acid, hydroquinone and hydrocortisone): clinical and histological studies. J Dermatol. 1998;25(9):587-96 (PubMed PMID: 9798345).

72. Chan R, Park KC, Lee MH, Lee ES, Chang SE, Leow $\mathrm{YH}$, et al. A randomized controlled trial of the efficacy and safety of a fixed triple combination (fluocinolone acetonide $0.01 \%$, hydroquinone $4 \%$, tretinoin $0.05 \%$ ) compared with hydroquinone $4 \%$ cream in Asian patients with moderate to severe melasma. Br J Dermatol. 2008;159(3):697-703 (PubMed PMID: 18616780).

73. Kauh YC, Zachian TF. Melasma. Adv Exp Med Biol. 1999;455:491-9 (PubMed PMID: 10599387).

74. Holme SA, Beattie PE, Fleming CJ. Cosmetic camouflage advice improves quality of life. Br J Dermatol. 2002;147(5):946-9 (PubMed PMID: 12410705).

75. Ahmed AM, Lopez I, Perese F, Vasquez R, Hynan LS, Chong B, et al. A randomized, double-blinded, placebo-controlled trial of oral Polypodium leucotomos extract as an adjunct to sunscreen in the treatment of melasma. JAMA Dermatol. 2013;149(8):981-3 (PubMed PMID: 23740292).

76. Choudhry SZ, Bhatia N, Ceilley R, Hougeir F, Lieberman R, Hamzavi I, et al. Role of oral Polypodium leucotomos extract in dermatologic diseases: a review of the literature. J Drugs Dermatol. 2014;13(2):148-53 (PubMed PMID: 24509964).

77. Arjinpathana N, Asawanonda P. Glutathione as an oral whitening agent: a randomized, double-blind, placebo-controlled study. J Dermatol Treatm. 2012;23(2):97-102 (PubMed PMID: 20524875).

78. Jang WS, Lee CK, Kim BJ, Kim MN. Efficacy of 694-nm Q-switched ruby fractional laser treatment of melasma in female Korean patients. Dermatol Surg. 2011;37(8):1133-40 (PubMed PMID: 21585597).

79. Katz TM, Glaich AS, Goldberg LH, Firoz BF, Dai T, Friedman PM. Treatment of melasma using fractional photothermolysis: a report of eight cases with long-term follow-up. Dermatol Surg. 2010;36(8):1273-80 (PubMed PMID: 20666816).

80. Park JM, Tsao H, Tsao S. Combined use of intense pulsed light and Q-switched ruby laser for complex dyspigmentation among Asian patients. Lasers Surg Med. 2008;40(2):128-33 (PubMed PMID: 18306166).

81. Rokhsar CK, Fitzpatrick RE. The treatment of melasma with fractional photothermolysis: a pilot study. Dermatol Surg. 2005;31(12):1645-50 (PubMed PMID: 16336881).

82. Wanitphakdeedecha R, Manuskiatti W, Siriphukpong S, Chen TM. Treatment of melasma using variable square pulse Er:YAG laser resurfacing. Dermatol Surg. 2009;35(3):475-81 (discussion 81-2. PubMed PMID: 19250309).

83. Rendon M, Cardona LM, Bussear EW, Benitez AL, Colon LE, Johnson LA. Successful treatment of moderate to severe melasma with triple-combination cream and glycolic acid peels: a pilot study. Cutis. 2008;82(5):372-8 (PubMed PMID: 19090343).

84. Javaheri SM, Handa S, Kaur I, Kumar B. Safety and efficacy of glycolic acid facial peel in Indian women with melasma. Int J Dermatol. 2001;40(5):354-7 (PubMed PMID: 11555002).

85. Hurley ME, Guevara IL, Gonzales RM, Pandya AG. Efficacy of glycolic acid peels in the treatment of melasma. Arch Dermatol. 2002;138(12):1578-82 (PubMed PMID: 12472345).

86. Kodali S, Guevara IL, Carrigan CR, Daulat S, Blanco $\mathrm{G}$, Boker A, et al. A prospective, randomized, split-face, controlled trial of salicylic acid peels in the treatment of melasma in Latin American women. J Am Acad Dermatol. 2010;63(6):1030-5 (PubMed PMID: 20889235). 
87. Kumari R, Thappa DM. Comparative study of trichloroacetic acid versus glycolic acid chemical peels in the treatment of melasma. Indian J Dermatol Venereol Leprol. 2010;76(4):447 (PubMed PMID: 20657143).

88. Hou A, Cohen B, Haimovic A, Elbuluk N. Microneedling: a comprehensive review. Dermatol Surg. 2017;43(3):321-39 (PubMed PMID: 27755171).

89. Cohen BE, Elbuluk N. Microneedling in skin of color: a review of uses and efficacy. J Am Acad Dermatol. 2016;74(2):348-55 (PubMed PMID: 26549251).

90. Taylor CR, Anderson RR. Ineffective treatment of refractory melasma and postinflammatory hyperpigmentation by Q-switched ruby laser. J Dermatol Surg Oncol. 1994;20(9):592-7 (PubMed PMID: 8089359).

91. Gokalp H, Akkaya AD, Oram Y. Long-term results in low-fluence 1064-nm Q-Switched Nd:yAG laser for melasma: is it effective? J Cosmet Dermatol. 2016;15(4):420-6 (PubMed PMID: 27349828).

92. Hofbauer Parra CA, Careta MF, Valente NY, de Sanches Osorio NE, Torezan LA. Clinical and histopathologic assessment of facial melasma after low-fluence Q-switched neodymium-doped yttrium aluminium garnet laser. Dermatol Surg. 2016;42(4):507-12 (PubMed PMID: 26963146).

93. Kauvar AN. The evolution of melasma therapy: targeting melanosomes using low-fluence Q-switched neodymium-doped yttrium aluminium garnet lasers. Semin Cutan Med Surg. 2012;31(2):126-32 (PubMed PMID: 22640433).

94. Yue B, Yang Q, Xu J, Lu Z. Efficacy and safety of fractional Q-switched 1064-nm neodymium-doped yttrium aluminum garnet laser in the treatment of melasma in Chinese patients. Lasers Med Sci. 2016;31(8):1657-63 (PubMed PMID: 27450275).

95. Yun WJ, Lee SM, Han JS, Lee SH, Chang SY, Haw S, et al. A prospective, split-face, randomized study of the efficacy and safety of a novel fractionated intense pulsed light treatment for melasma in Asians. J Cosmet Laser Ther. 2015;17(5):259-66 (PubMed PMID: 25803571).

96. Tong LG, Wu Y, Wang B, Xu XG, Tu HD, Chen HD, et al. Combination of fractional QSRL and IPL for melasma treatment in chinese population. J Cosmet Laser Ther. 2016;3:1-19 (PubMed PMID: 27594596).

97. Angsuwarangsee S, Polnikorn N. Combined ultrapulse $\mathrm{CO}_{2}$ laser and Q-switched alexandrite laser compared with Q-switched alexandrite laser alone for refractory melasma: split-face design. Dermatol Surg. 2003;29(1):59-64 (PubMed PMID: 12534514).

98. Nouri K, Bowes L, Chartier T, Romagosa R, Spencer J. Combination treatment of melasma with pulsed $\mathrm{CO}_{2}$ laser followed by Q-switched alexandrite laser: a pilot study. Dermatol Surg. 1999;25(6):494-7 (PubMed PMID: 10469101).

99. Jalaly NY, Valizadeh N, Barikbin B, Yousefi M. Low-power fractional $\mathrm{CO}(2)$ laser versus low-fluence Q-switch 1,064 nm Nd:yAG laser for treatment of melasma: a randomized, controlled, split-face study. Am J Clin Dermatol. 2014;15(4):357-63 (PubMed PMID: 24858737).

100. Cameli N, Abril E, Mariano M, Berardesca E. Combined use of monopolar radiofrequency and transdermal drug delivery in the treatment of melasma. Dermatol Surgery. 2014;40(7):748-55 (PubMed PMID: 25111347). 